\title{
Pemanfaatan Serbuk Cangkang Bekicot dan Serbuk Cangkang Kerang Pada Bata Beton Ringan Selular Ditinjau Dari Berat Volume dan Pengaruh Pengovenan Terhadap Uji Tekan Pada Umur 28 Hari
}

\author{
Utilization of Snail Shell Powder and Shell Shell Powder in Cellular \\ Lightweight Concrete Brick Judging from Volume Weight and Effect of \\ Covenant on Compressive Test at 28 Days
}

\author{
Mochamad Firmansyah Sofianto ${ }^{1}$ \\ ${ }^{1}$ Jurusan Teknik Sipil, Fakultas Teknik, Universitas Negeri Surabaya, Jl. Ketintang Surabaya. \\ Email : mochamadfirmansyah@unesa.ac.id
}

\begin{abstract}
Abstrak
Bata Beton Ringan seluler (Cellular lightweight concrete - CLC) adalah alternatif material dinding yang sering digunakan dikonstruksi gedung. Serbuk Cangkang Bekicot (SCB) dan Serbuk Cangkang Kerang (SCK) merupakan limbah produksi rumahan didaerah Kediri dan Sidoarjo. Kandungan senyawa kimia dari kedua bahan tersebut adalah dominan senyawa Calsium (Ca), sehingga senyawa ini dapat digunakan sebagai pengganti semen. Tujuan penelitian ini adalah untuk mengetahui pengaruh penggunaan kedua bahan tersebut dalam Bata Beton Ringan pada berat volume dan nilai uji tekannya. Pembuatan Bata Beton Ringan CLC dilakukan di PT Banancon dan pembuatan bata CLC ini menggunakan Foaming Agent sebagai bahan pembuat gelembung yang dicampurkan dengan pasta dan bahan limbah. Hasil penelitian tersebut bahwa penggunaan bahan SCB dan SCK dapat mempengaruhi dari kualitas Bata Beton Ringan, menggunakan bahan SCB dapat meningkatkan berat volume Bata Beton Ringan sebesar $1.2928 \mathrm{gr} / \mathrm{cm}^{3}$ atau peningkatan sebesar $1.44 \%$ dari nilai berat volume dengan dengan proporsi 0\%. Untuk hasil berat volume penggunaan bahan SCK tidak terlalu berarti perubahannya. Nilai uji tekan tanpa pengovenan, dengan bahan SCB terjadi peningkatan dibandingkan nilai SCK, nilai maksimum peningkatan sampai prosentase 4\% sebesar 4.616 MPa. Nilai uji tekan dengan pengovenan peningkatan terjadi pada 6\% sebesar 4.935 MPa. Sebaliknya, nilai uji tekan pada SCK terjadi penurunan cukup drastis, sehingga disimpulkan bahwa Bata Beton Ringan dengan bahan SCB lebih tepat untuk digunakan sebagai bahan pengganti semen.
\end{abstract}

Kata Kunci: Bata Beton Ringan Selular, Cangkang Bekicot, Cangkang Kerang, Berat Volume, Nilai Tekan

\begin{abstract}
Cellular Lightweight Concrete Brick (CLC) is a material alternative that always used in building construction. Snail Shells Powder (SCB) and Shell Shells Powder (SCK) are home industry waste material from Kediri and Sidoarjo. Chemical compound of both waste materials is dominantly calcium. Therefore, these chemical compounds can use to replace the cement composition. The objection of this research is to find out the affect of SCB dan SCK on Cellular Lightweight Concrete Brick into density and compression value. Fabrication of Cellular Lightweight Concrete Brick is conducted at PT. Banancon Sidoarjo and the fabrication of CLC brick use Foaming Agent as a bubble maker chemical then mixing into mortar concrete and waste materials. The result that using waste material SCB and SCK on CLC brick can affect the quality of CLC brick. CLC brick with SCB material can increased density of mortar CLC brick with value $1.2928 \mathrm{gr} / \mathrm{cm}^{3}$ or percentage of enhancement is $1.44 \%$ from density value on $0 \%$ percentage of SCB. For density value on CLC brick with SCK does not to show significantly increased value. Compression value without drying by oven on SCB material shows increase value than CLC with SCK material, maximum value of increasing compression test is 4.616 $M P a$ on $4 \%$ of SCB material. In addition, compression value with drying by oven is increasing constantly until $6 \%$ of SCB with $4.935 \mathrm{MPa}$. In other hand, compression value of CLC with SCK material show drastically
\end{abstract}


decrease, therefore from all experiment, this research can be concluded that CLC with SCB material is more appropriate to use as a substitute for cement.

Keywords: Cellular Lightweight Concrete Brick, Snail Shells, Shell Shells, Density, Compression Test.

\section{PENDAHULUAN}

Perkembangan teknologi dibidang material konstruksi bangunan gedung mengalami peningkatan yang cukup pesat dalam menciptakan suatu variasi ataupun alternatif didalam penggunaannya. Berbagai jenis dan alternatif material tersebut salah satunya dalam penggunaan material dinding partisi. Dinding partisi adalah salah satu jenis material utama yang sering digunakan dalam pekerjaan konstruksi gedung, karena berfungsi sebagai penyekat ruangan dan pengisi celah diantara kolom. Dalam segi perencanaan, dinding partisi ini berfungsi sebagai beban yang ditahan oleh balok, karena pekerjaan pemasangan dinding terletak diatas balok. Oleh karena itu, material konstruksi dinding yang terbaru yang telah berkembang adalah material dinding bata beton ringan, dimana berat dinding tersebut cenderung ringan.

Serbuk Cangkang Bekicot merupakan limbah dari produksi dari industri rumahan yang membudidayakan bekicot yang akan digunakan untuk bahan makanan. Sisa cangkang bekicot tersebut dikumpulkan dan digunakan sebagai bahan tambah dalam makanan ternak yaitu unggas ataupun sapi. Sementara Serbuk Cangkang Kerang diambil dari sisa limbah produksi kerang, yaitu disini kerang darah yang digunakan. Hasil limbah tersebut selain dimanfaatkan sebagai bahan lainnya, dapat digunakan sebagai bahan alternatif dalam bidang konstruksi.

Hasil uji kimia untuk Serbuk Cangkang Bekicot kering dan Serbuk Cangkang Kerang yang paling dominan mengandung $\mathrm{Ca}$ (Calsium) yaitu SCB sebesar $97.46 \%$ dan SCK yaitu sebesar 95.60\% (Hasil Uji XRF SCB dan SCK dari Lab Kimia UM Malang). Dengan kondisi senyawa kimia dari SCB dan SCK tersebut, dapat diasumsikan bahwa serbuk tersebut dapat digunakan sebagai pengganti bahan semen, akan tetapi tidak cukup apabila dengan menggunakan serbuk tersebut, sehingga dalam pencampuran mix desain dari SCB dan SCK perlu ditambahkan Fly-Ash. Serbu Fly-Ash memiliki kandungan Fe dan Si yang cukup dominan (Hasil Uji XRF Fly-Ash dari Lab Kimia UM Malang), sehingga serbuk tersebut dapat bereaksi sebagaimana semen bereaksi ketika bercampuran dengan air.

Bata beton ringan selular atau dikenal produksi dipasaran adalah Cellular Lightweight Concrete (CLC) merupakan produksi material dinding ringan yang terbuat dari campuran semen, pasir silika, air dan Foam agent. Foam agent ini merupakan bahan aditif tambahan yang membuat gelembung air yang merupakan campuran dari foam agent dan air, yang kemudian ditambahkan dalam campuran mortar bata beton ringan tersebut. Pada penelitian Tansajaya, dkk (2011) tentang studi pembuatan Celluar Lightweight Concrete (CLC) dimana pembuatannya menggunakan variasi konsentrasi pada foam agent. Dari hasil penelitiannya didapatkan bahwa ukuran gelembung yang dihasilkan oleh foam agent tipe lain menyebabkan luas permukaan yang menerima beban semakin kecil sehingga kuat tekannya berkurang. Sehingga pada pembuatan bata beton ringan tentunya digunakan yang menghasilkan gelembung yang cenderung homogeny kecil yang dapat memberikan luasan yang cukup besar dan lebih massif ikatan antar partikelnya.

Perkembangan produk Bata Beton Ringan ditunjukan pada penelitian lain yaitu penelitian Willy Aryansyah P, dkk., (2015) tentang penambahan bahan Zeolite alam yang tertahan saringan No. 80 dan No. 200 pada campuran Bata Beton Ringan menunjukan bahwa kuat tekan Bata Beton Ringan penambahan 20\% Zeolite alam 40\% lebih besar dibandingkan Bata Beton Ringan Normal, dan nilai hubungan tegangan-regangan semakin tegak ke arah tegangan. Hal ini menunjukan sifat Bata Beton Ringan cenderung lebih getas dibandingkan sebelumnya. Jumlah Silika yang cukup banyak pada bahan Zeolite alam yang menyebabkan nilai kuat tekan meningkat.

Berdasarkan penelitian sebelumnya, sebelum dilakukan pengujian, Bata Beton Ringan hanya dibiarkan begitu saja setelah dilakukan perendaman atau perawatan. Proses pengeringan setelah perawatan tersebut dilakukan dengan membiarkan bata beton ringan tersebut diangin-anginkan saja dengan suhu ruang ataupun suhu luar (yang secara 
tidak langsung tersinari matahari). Tentunya, proses pengeringan bata beton ringan akan mempercepat proses pengerasan campuran pasta yang terdapat Bata Beton Ringan tersebut, akan tetapi seberapa signifikan nilai yang diberikan oleh proses pengeringan tersebut.

Oleh karena itu, pada penelitian ini akan membahas bagaimana hasil uji kuat tekan dan porositas pada Bata Beton Ringan bahan SCB dan SCK dengan Fly-Ash dengan atau tanpa metode proses pengeringan.

\section{METODE}

Bata Beton Ringan merupakan produk pembuatan bata dari material beton yang memiliki syarat ringan sesuai dengan acuan SNI 03-3449-1994 tentang syarat beton ringan. Namun, produk Bata Beton Ringan ini sebagai material non-struktural, maka persyaratan minimum dari kuat tekan tidak dapat dijadikan sebagai acuan, hanya persyaratan berat dari produk ini yang perlu dikontrol. Pada umumnya, syarat berat yang dijadikan referensi pada Bata Beton Ringan yaitu antara $600 \mathrm{~kg} / \mathrm{m}^{3}-$ $1600 \mathrm{~kg} / \mathrm{m}^{3}\left(0.6 \mathrm{gram} / \mathrm{cm}^{3}-1.6 \mathrm{gram} / \mathrm{cm}^{3}\right)$.

Penelitian ini dilaksanakan secara eksperimental, dimana benda uji dibuat di pabrik sesuai dengan mix desain rencana kemudian diujikan tekan di laboratorium bahan Unesa. Komposisi campuran Bata Beton Ringan mengacu pada mix desain campuran penelitian Risdanareni, dkk., 2016, bahwa hasil yang bagus untuk campuran pembuatan Bata Beton Ringan antara semen : pasir yaitu $1: 2$ dengan nilai water-binder rasio sebesar 0.5 terhadap berat volume. Sehingga, pada penelitian ini ditentukan campuran Bata Beton Ringan antara semen : pasir : air yaitu $1: 2: 0.5$ dan pembuatan gelembung busa dengan berbandingan antara Foaming Agent : air yaitu $1: 20$. Proses pembuatan dan pencetakan benda uji dilakukan dipabrik PT. Banan-Con di Jalan Raya Juanda Surabaya. Material yang digunakan adalah semen PPC, pasir silika yang disediakan oleh pabrik dan sudah diuji kualitasnya, air bersih dan Foaming Agent yang disediakan oleh Pabrik.

Tabel 1. Komposisi Mix Desain Campuran Bata Beton Ringan (SCB dan Fly Ash)

\begin{tabular}{ccccccc}
\hline \multirow{2}{*}{ Kode } & \multirow{2}{*}{ Pasir } & \multicolumn{3}{c}{ Bahan } & \multirow{2}{*}{$\begin{array}{c}\text { Foaming } \\
\text { Angent }\end{array}$} \\
\cline { 3 - 6 } V1 & 2 & Semen & FA & SCB & & $\begin{array}{c}\text { Agent } \\
\text { V2 }\end{array}$ \\
\hline V3 & 2 & 0.95 & 0.05 & 0 & 0.5 & 0.06 \\
\hline V4 & 2 & 0.91 & 0.05 & 0.02 & 0.5 & 0.06 \\
\hline V5 & 2 & 0.89 & 0.05 & 0.06 & 0.5 & 0.06 \\
\hline
\end{tabular}

Tabel 2. Komposisi Mix Desain Campuran Bata Beton Ringan (SCK dan Fly Ash)

\begin{tabular}{ccccccc}
\hline Kode & Pasir & \multicolumn{3}{c}{ Bahan } & \multirow{2}{*}{ Air } & $\begin{array}{c}\text { Foaming } \\
\text { Agent }\end{array}$ \\
\cline { 3 - 5 } V1 & 2 & Semen & FA & SCK & & 0.95 \\
\hline V2 & 2 & 0.05 & 0 & 0.5 & 0.06 \\
\hline V3 & 2 & 0.91 & 0.05 & 0.02 & 0.5 & 0.06 \\
\hline V4 & 2 & 0.89 & 0.05 & 0.06 & 0.5 & 0.06 \\
\hline V5 & 2 & 0.87 & 0.05 & 0.08 & 0.5 & 0.06 \\
\hline
\end{tabular}

Dari setiap mix desain akan dibuat ukuran benda uji yaitu $5 \mathrm{~cm} \times 5 \mathrm{~cm} \times 5 \mathrm{~cm}$ sebanyak 10 buah setiap benda ujinya, dan diujikan pada umur 28 hari. Metode pencampuran dari Bata Beton Ringan yaitu pencampuran semen, pasir dan air untuk pasta Bata Beton Ringan terlebih dahulu di dalam mesin pencampuran. Pembuatan busa dilakukan di generator busa (Foam Generator) dengan campuran dari Foaming Agent dengan Air yang sudah disiapkan. Setelah pasta Bata Beton Ringan dan busa dari foam generator sudah siap, busa disaring dengan lubang gelembung yang diameter kecil kemudian dicampurkan ke dalam campuran pasta Bata Beton Ringan tersebut.

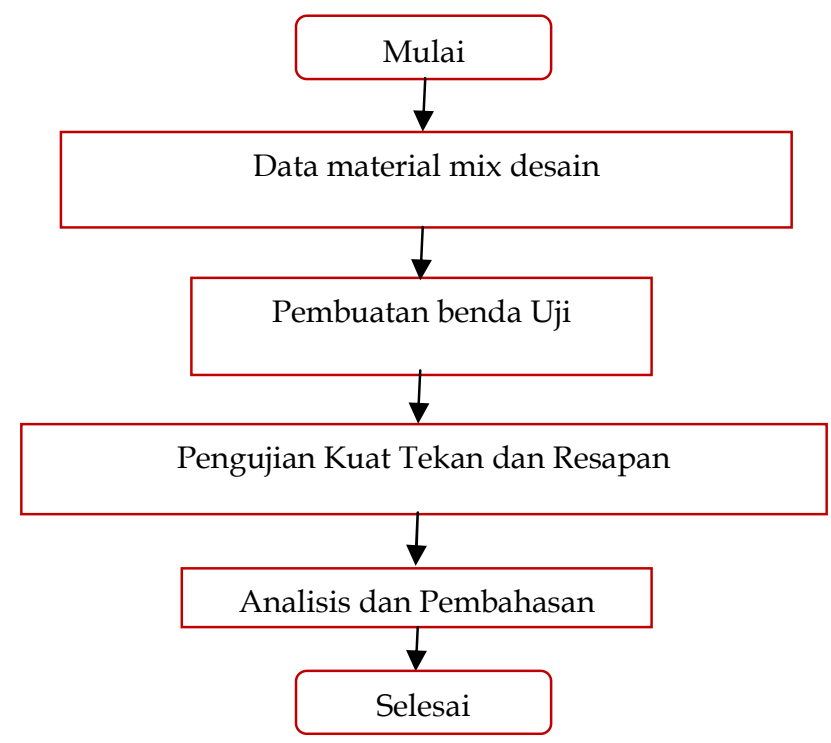

Gambar 1. Diagram Alir Penelitian

\section{HASIL DAN PEMBAHASAN}

Pengujian Berat Volume Bata Beton Ringan

Hasil uji berat volume dengan bahan SCB dan SCK pada Bata Beton Ringan sebagai pengganti semen pada umur 28 hari dapat dilihat tabel dan grafik dibawah ini. 
Tabel 3. Hasil Uji Berat Volume Bata Beton Ringan

\begin{tabular}{cccc}
\hline $\begin{array}{c}\text { Variasi } \\
\text { SCB }\end{array}$ & $\begin{array}{c}\text { Berat Volume } \\
(\mathrm{gr} / \mathrm{cm} 3)\end{array}$ & $\begin{array}{c}\text { Variasi } \\
\text { SCK }\end{array}$ & $\begin{array}{c}\text { Berat Volume } \\
(\mathrm{gr} / \mathrm{cm} 3)\end{array}$ \\
\hline SCB $0 \%$ & 1.3245 & SCK 0\% & 1.1604 \\
\hline SCB 2\% & 1.2928 & SCK 2\% & 1.1664 \\
\hline SCB 4\% & 1.2656 & SCK 4\% & 1.1744 \\
\hline SCB 6\% & 1.2448 & SCK 6\% & 1.1728 \\
\hline SCB 8\% & 1.2243 & SCK 8\% & 1.1786 \\
\hline
\end{tabular}

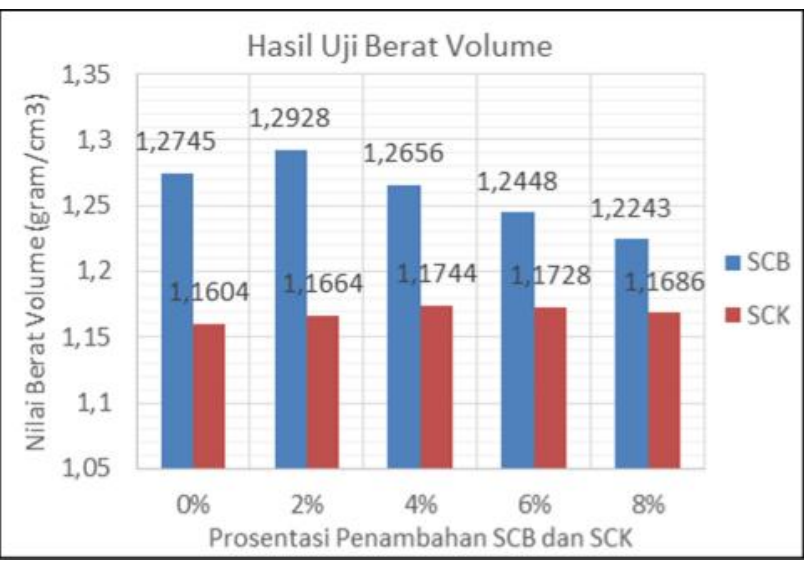

Gambar 1. Grafik Hasil Uji Berat Volume

Dari hasil uji berat volume diatas, diketahui bahwa penggunaan SCB dan SCK memeberikan pengaruh terhadap berat volume dari bata beton ringan. Untuk penggunaan SCB kecenderungannya penambahan berat volume pada prosentase sebesar $2 \%$ dari acuan tanpa SCB atau prosentase $0 \%$. Sementara untuk penggunaan SCK peningkatan berat volume terjadi pada prosentase sebesar 4\%. Dari ke-2nya selanjutnya mengalami penurunan bersamaan dengan penambahan jumlah prosentase dari SCB dan SCK. Hal ini disebabkan karena senyawa yang dominan dikandung kedua bahan adalah Calsium (Ca) dapat menurunkan kuat tekan beton itu sendiri. Sehingga dengan kondisi tersebut menyebabkan penurunan berat volume dari bahan mix yang bahan dasarnya terlalu banyak senyawa Calsiumnya,

Untuk perbandingan kedua bahan yang ditambahkan pada pembuatan Bata Beton Ringan, untuk bahan penggunaan SCB lebih memberikan berat volume cukup besar dibandingkan SCK. Hal ini disebabkan karena karakteristik butiran dari SCB dan SCK berbeda ditinjau dari kemampuan menyerap air. Untuk Butiran SCB cenderung tidak menyerap air sehingga dapat berfungsi sebagai filler dalam mortar semen. Sementara SCK mampu menyerap air cukup banyak, sehingga proses pengerasan dari mortar bata beton ringan terganggu dan tidak sempurna maka banyak rongga-rongga yang tidak dapat terisi.

\section{Pengujian Kuat Tekan Pada Kondisi Tanpa Pengovenan Bata Beton Ringan}

Hasil pengujian kuat tekan Bata Beton Ringan dengan bahan SCB dan SCK sebagai pengganti semen pada umur 28 hari tanpa perilaku benda uji dengan pengovenan dapat ditampilkan pada tabel dan grafik dibawah ini.

Tabel 4. Hasil Uji Tekan Bata Beton Ringan Tanpa Perilaku Pengovenan

\begin{tabular}{cccc}
\hline $\begin{array}{c}\text { Variasi } \\
\text { SCB }\end{array}$ & $\begin{array}{c}\text { Uji Tekan } \\
(\mathrm{MPa})\end{array}$ & $\begin{array}{c}\text { Variasi } \\
\text { SCK }\end{array}$ & $\begin{array}{c}\text { Uji Tekan } \\
(\mathrm{MPa})\end{array}$ \\
\hline SCB 0\% & 4.072 & SCK 0\% & 3.864 \\
\hline SCB 2\% & 4.024 & SCK 2\% & 3.752 \\
\hline SCB 4\% & 4.616 & SCK 4\% & 3.392 \\
\hline SCB 6\% & 4.304 & SCK 6\% & 3.896 \\
\hline SCB 8\% & 3.424 & SCK 8\% & 3.736 \\
\hline
\end{tabular}

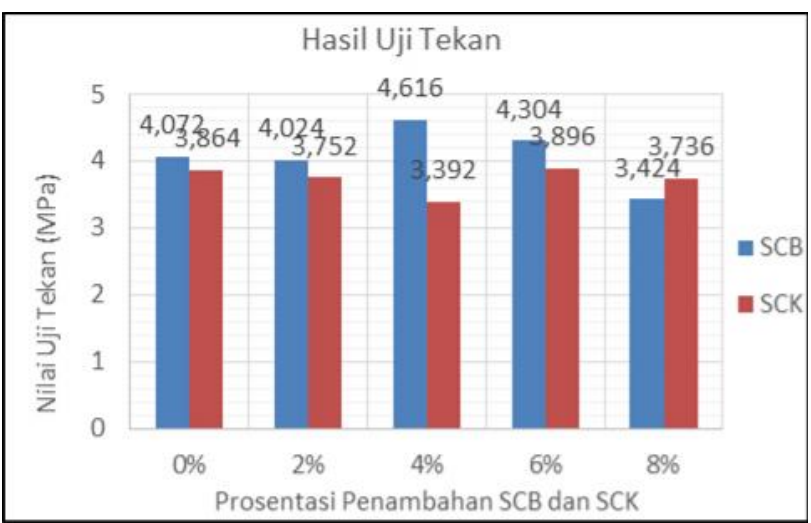

Gambar 2. Grafik Hasil Uji Tekan Bata Beton Ringan Tanpa Pengovenan

Pada hasil uji tekan pada Bata Beton Ringan tanpa dilakukan pengeringan ini diambil dari benda uji yang dilakukan perawatan saja. Dari hasil tersebut menunjukan bahwa terjadi peningkatan nilai uji tekan Bata Beton Ringan dengan penggunaan bahan SCB yaitu pada prosentasi $4 \%$ sebesar $4.616 \mathrm{MPa}$, hal ini disebabkan karakteristik butiran SCB yang mampu menggantikan semen dalam pengikatan, tetapi akan lebih baik apabila senyawa kandungan SCB ditingkatkan dengan cara dibakar dengan suhu $800 \mathrm{oC}$ agar terciptanya kristalisasi sehingga proses pengerasan dari mortar beton sempurna. Sementara pada penggunaan bahan SCK terjadi penurunan nilai tekan sampai $4 \%$, kemudian mengalami peningkatan nilai tekan yang nilainya hampir sama dengan Bata Beton Ringan sebelum digunakan bahan SCK atau prosentase sebesar 0\%. Hal ini disebabkan oleh karakteristik dari SCK yang belum sempurna dan penyerapan yang cukup tinggi, sehingga semen kekurangan air dalamn proses pengerasan pada Bata Beton Ringan. 


\section{Pengujian Kuat Tekan Pada Kondisi Dengan Diperlakukan Pengovenan Bata Beton Ringan}

Hasil pengujian kuat tekan Bata Beton Ringan dengan bahan SCB dan SCK sebagai pengganti semen pada umur 28 hari tanpa perilaku benda uji dengan pengovenan dapat ditampilkan pada tabel dan grafik dibawah ini.

Tabel 5. Hasil Uji Tekan Bata Beton Ringan Dengan Perilaku Pengovenan

\begin{tabular}{cccc}
\hline $\begin{array}{c}\text { Variasi } \\
\text { SCB }\end{array}$ & $\begin{array}{c}\text { Uji Tekan } \\
(\mathrm{MPa})\end{array}$ & $\begin{array}{c}\text { Variasi } \\
\text { SCK }\end{array}$ & $\begin{array}{c}\text { Uji Tekan } \\
(\mathrm{MPa})\end{array}$ \\
\hline SCB 0\% & 4.366 & SCK 0\% & 4.423 \\
\hline SCB 2\% & 4.512 & SCK 2\% & 4.264 \\
\hline SCB 4\% & 4.752 & SCK 4\% & 4.072 \\
\hline SCB 6\% & 4.936 & SCK 6\% & 3.988 \\
\hline SCB 8\% & 4.754 & SCK 8\% & 3.812 \\
\hline
\end{tabular}

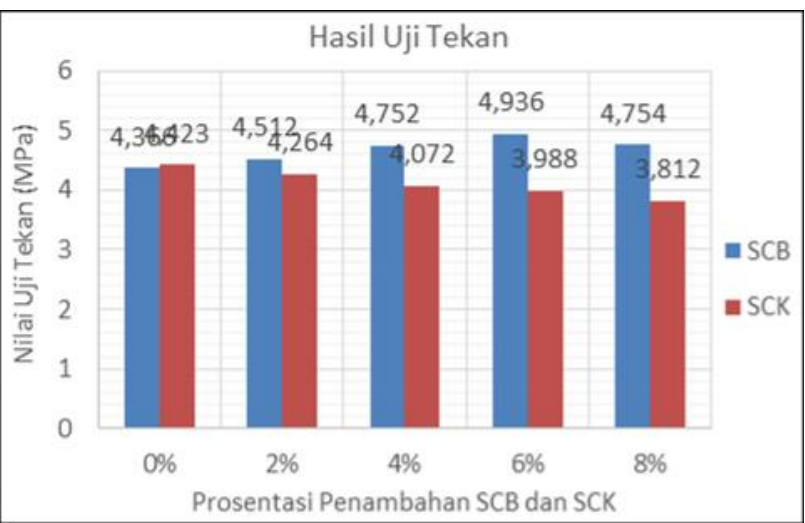

Gambar 3. Grafik Hasil Uji Tekan Bata Beton Ringan Dengan Pengovenan

Hasil uji tekan pada Bata Beton Ringan dengan pengovenan menunjukan bahwa terjadi peningkatan nilai kuat tekan pada benda uji dengan penggunaan bahan SCB dimana peningkatan nilai tidak terlalu signifikant dari prosentase $0 \%$ sampai $6 \%$, namun terjadi penurunan kekuatan setelah itu namun nilanya juga tidak terlalu jauh penurunannya. Sementara nilai uji tekan pada Bata Beton Ringan yang menggunakan bahan SCK terjadi penurunan yang cukup jelas dari prosentase $0 \%$ hingga $8 \%$. Maka pengaruh pengovenan cukup jelas pada penggunaan prosentase SCB maupun SCK, sebaliknya pada bahan SCK tidak mampu memperbaiki nilai uji tekan apabila Bata Beton Ringan diperlakukan dengan pengovenan.

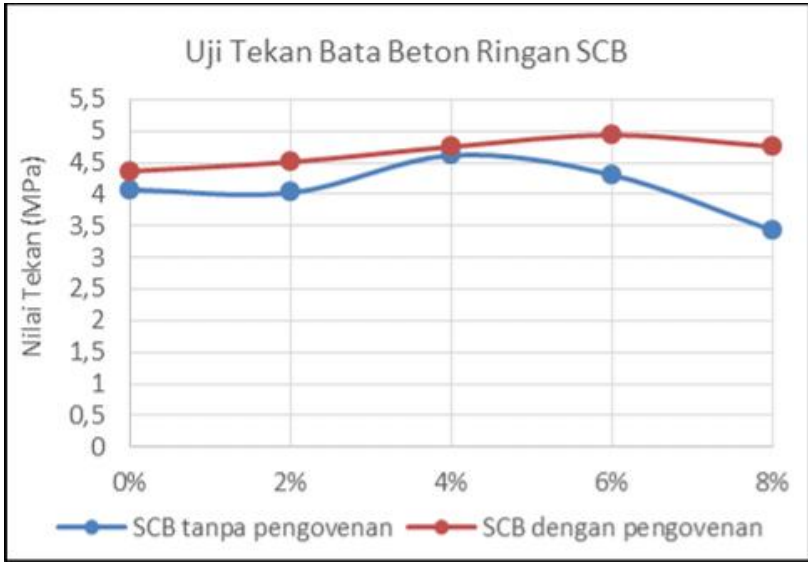

Gambar 4. Perbandingan Bata Beton Ringan SCB Tanpa dan Dengan Pengovenan

Pada grafik diatas menjelaskan bahwa nilai uji tekan Bata Beton Ringan dengan menggunakan bahan SCB tanpa dan dengan pengovenan. Dari grafik tersebut jelas menunjukan bahwa pengaruh dari perlakukan pengovenan dapat meningkatkan kualitas nilai uji tekan Bata Beton Ringan. Hal ini disebabkan dengan proses pengovenan dapat mempercepat proses reaksi kimia dan pengikatan material beton, selain itu SCB dapat bereaksi dengan baik apabila dilakukan pemanasan pada material SCB ini. Maka kualitas Bata Beton Rignan dapat dilihat dari meningkatnya nilai uji tekan benda uji.

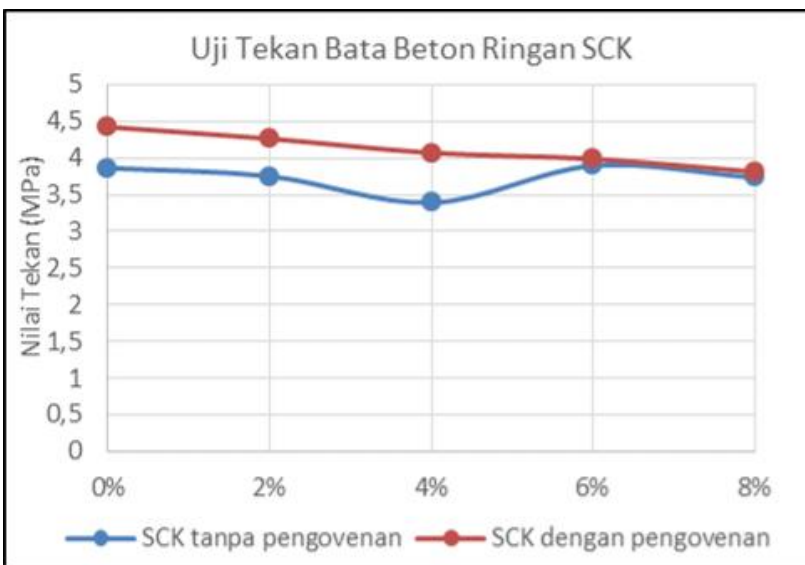

Gambar 5. Perbandingan Bata Beton Ringan SCK Tanpa dan Dengan Pengovenan

Sementara pada grafik hubungan tanpa dan dengan dilakukan pengovenan pada Bata Beton Ringan menggunakan bahan SCK menunjukan penurunan nilai uji tekan beton atau cenderung tidak ada perubahan pada pembuatan benda ujinya. Sebaliknya, benda uji dengan perlakukan pengovenan mengalami penurunan kualitas Bata Beton Ringan. Oleh karena itu tidaklah cocok untuk benda uji dengan menggunakan SCK untuk dilakukan pengovenan. 
Pada penelitian ini, penggunaan SCB sangat lebih tepat untuk menggantikan peran semen dalam merekatkan antar partikel didalam Bata Beton Ringan. Selain itu, butiran dari SCB cenderung menjadi pengisi didalam pasta semen sehingga dapat memberikan hasil yang baik dalam kuat tekan dibandingkan dengan Bata Beton Ringan dengan bahan SCK. Maka dapat disimpulkan bahwa penggunaan bahan SCB dapat memperbaiki kualitas Bata Beton Ringan dibandingkan dengan menggunakan bahan SCK.

\section{SIMPULAN}

Simpulan yang diperoleh dari penelitian tersebut:

1. Penggunaan bahan SCB mampu menambah berat volume dari Bata Beton Ringan secara optimum pada prosentase $2 \%$.

2. Nilai uji tekan yang mampu diperbaiki dengan menggunakan bahan SCB hingga prosentase SCB sebesar 4\% dibandingkan menggunakan bahan SCK yang tidak mampu memperbaiki nilai uji tekan.

3. Nilai uji tekan dengan dilakukan pengovenan untuk Bata Beton Ringan dengan bahan SCB menunjukan hasil peningkatan nilai tekan hingga mencapai prosentase $6 \%$, sementara untuk SCK tidak mampu memperbaiki nilai uji tekan Bata Beton Ringan.

4. Bahan pengganti semen yang mampu memperbaiki kualitas dari Bata Beton Ringan yaitu dengan menggunakan bahan Serbuk Cangkang Bekicot (SCB) dibandingkan Serbuk Cangkang Kerang (SCK).

\section{REFERENSI}

Hunggurami E., Bunganaen W., dan Muskanan R. Y., 2014, "Studi Eksperimental Kuat Tekan dan Serapan Air Bata Ringan Cellular Lightweight Concrete Dengan Tanah Puth sebagai Agregrat", Jurnal Teknik Sipil, Vol. III, No. 2, September 2014.

Zuraidah S. dan Hstono B., 2017, "Serbuk Kapur Sebagai Cementitious Pada Mortar", Jurnal Rekayasa Teknik Sipil Universitas Madura, Vol. 2, No. 1, Juni 2017, ISSN 2527-5542.

Pratama W. A., Anggraini R., Zacoeb A., dan Wahyuni E., 2015, "Perbandingan Kuat Tekan dan Tegangan-Regangan Bata Beton Ringan Dengan Penambahan Mineral Alami Zeolit Alam Tertahan Saringan No. $80(0,180$ $\mathrm{mm})$ dan Tertahan Saringan No. $200(0,075$ mm)", Rekayasa Sipil, Volume 9, No. 3 2015 ISSN 1978 - 5658.

Qoniah I., dan Prasetyoko D., "Penggunaan Cangkang Bekicot Sebagai Katalis Untuk Reaksi Transesterifikasi Refined Palm Oil", Prosiding Skripsi Semester Genap 2010/2011.

Syafpoetri N. A., Djauhari Z., dan Olivia M., 2018, "Karakteristik Mortar Dengan Campuran Abu Kerang Lokan Dalam Rendaman $\mathrm{NaCl}$ ", Jurnal Rekayasa Sipil (JRS-UNAND), Vol. 14, No. 1, Februari 2018.

Reni Y. C., Hastuti R., dan Darmawan A., 2009, "Kajian Pengaruh Penambahan Kalsium Oksida $(\mathrm{CaO})$ Terhadap Suhu Reaksi dan Kuat Tekan Semen Portland", InstitusionalRespository, UNDIP-IR, Desember 2009.

Tansanjaya, Anita, dan Tjahjana W. N. K., 2008, "Studi Pembuatan Cellular Lightweight Concrete (CLC) Dengan Menggunakan Beberapa Foaming Agent", Scientific Repository - Petra Christian University, Surabaya, April 2011. 